\title{
Civil Rights vs. Civil Liberties? The Legality of State Court Lawsuits under the Fair Housing Act
}

\author{
David Franklin†
}

Consider the following scenario: An individual contracts to purchase a house in a single-family neighborhood, intending to use the property as a group home for mentally handicapped teenagers. Local residents are concerned about the impact these newcomers will have on their neighborhood. The residents file a lawsuit in state court, seeking to enjoin the operation of the group home on the grounds that its intended occupants fail to satisfy the local zoning ordinance's definition of "family." The group home operator answers that such an application of the zoning ordinance would be discriminatory and therefore invalid under the Fair Housing Act ("FHA"). ${ }^{1}$ The FHA prohibits discrimination in housing on the basis of handicap, and expressly preempts state and local laws that conflict with it. ${ }^{2}$

Eventually the neighbors drop the case, but the group home operator claims that she and the handicapped teenagers have suffered significant damages as a result of the lawsuit, in the form of adverse publicity, emotional distress, delay, substitute housing costs, and legal fees. Consequently, she sues the neighbors in federal court, arguing that the filing and prosecution of the state court lawsuit constituted discrimination in violation of the FHA. $^{3}$ The neighbors respond that their litigation activity was protected by the First Amendment. ${ }^{4}$

$\dagger$ B.A. 1990, Yale University; J.D. Candidate 1997, The University of Chicago.

142 USC $\S 3601$ et seq (1994), originally enacted as Title VIII of the Civil Rights Act of 1968. The group home operator might also attempt to remove the zoning case to federal court or ask a federal court to enjoin the state suit. See notes 78, 80 .

2 The FHA also forbids discrimination on the basis of race, color, religion, national origin, sex, and familial status. 42 USC $\S 3604$.

3 This Comment addresses only the claim that the filing of a civil suit by private individuals may constitute a violation of the FHA. Criminal prosecutions and zoning enforcement actions brought by municipalities present distinct problems.

1 The facts of United States $v$ Robinson, Fair Housing-Fair Lending (P-H) II 15,979 (D Conn 1995), form the basis of this hypothetical, with significant changes. For a discussion of Robinson, see text accompanying notes 81-86. 
How should the court rule? Should the right to sue be absolute in this setting? If not, where should the line be drawn-what types of litigation activity should be constitutionally protected and what types should be subject to liability under the FHA? Would it make a difference if the challenged state court action had sought to enforce a (private) restrictive covenant rather than a (public) zoning ordinance? Should the neighbors' intent in bringing the lawsuit matter? These questions test the boundaries of the First Amendment in the context of federal civil rights legislation. This Comment offers the courts some much needed guidance in drawing those boundaries.

These issues have generated controversy outside the courtroom as well. On several occasions in recent years, the Departments of Justice and Housing and Urban Development ("HUD") have pursued federal claims on behalf of state court defendants, arguing that the filing of state court lawsuits may violate the FHA. However, the government's position in these cases and investigations has been heavily criticized ${ }^{5}$ and it is unclear to what extent federal enforcement agencies will continue to pursue such claims. ${ }^{6}$ Congress, too, appears concerned that the FHA is being used by government lawyers to prevent local residents from using the courts to protect the character of their communities. ${ }^{7}$

5 See, for example, Nat Hentoff, HUD's Attack on the First Amendment, Wash Post A15, A15 (Sept 17, 1994); Sigfredo A. Cabrera, Rule of Law: HUD Continues its Assault on Free Speech, Wall St J A15, A15 (June 7, 1995). For an even-handed overview of the major cases and investigations, see Katherine Pfleger, Rights in Conflict, Govt Exec 54 (Nov 1995).

6 In response to negative publicity surrounding its 1994 investigations in Bakersfield and Berkeley, California, HUD issued new guidelines that appear to prohibit its lawyers from investigating or filing cases with First Amendment implications. See Memorandum to Fair Housing and Equal Opportunity Directors, et al, from Roberta Achtenberg, Assistant Secretary of HUD for Fair Housing and Equal Opportunity, Substantive and Procedural Limitations on Filing and Investigating Fair Housing Act Complaints that May Implicate the First Amendment (Sept 2, 1994) (on file with U Chi L Rev). The Justice Department, however, has filed and won at least one such case since the new HUD guidelines went into effect. See United States $v$ Wagner, 1996 US Dist LEXIS 4148, *33-34 (N $\mathrm{D}$ Tex) (holding that the First Amendment does not shield neighbors from FHA liability for suing to exclude a group home for retarded children from neighborhood).

7 A recently enacted appropriations act prevents HUD lawyers from pursuing claims during fiscal year 1996 alleging that nonfrivolous state court litigation violates the FHA. See Omnibus Consolidated Rescissions and Appropriations Act of 1996, § 223, Pub L No 104-134, 110 Stat 1321. However, the passage of this legislation does little to answer the questions addressed by this Comment, for two reasons. First, even under this appropriations act, the Department of Justice can continue to bring cases alleging discriminatory filing of zoning actions under 42 USC § 3614(a), which authorizes the Attorney General to initiate cases alleging a "pattern or practice" of discrimination in housing. Second, the bill does not bar suits brought by private parties, as authorized by 42 USC $\S 3613$. A separate 
Meanwhile, courts have struggled with this new area of law, borrowing inconsistent and unsatisfactory standards from other statutory contexts to fill the gap. This Comment offers guidance to the courts by outlining a workable standard of liability for litigation under the Fair Housing Act.

Part I of this Comment describes the relevant provisions of the Fair Housing Act, its preemptive scope, and its interaction with state and local property and zoning laws. It concludes that Congress intended the FHA to invalidate local land use rules, zoning decisions, and deed restrictions insofar as these operate to discriminate against protected groups. The text and legislative history of the FHA do not, however, indicate whether it was intended to cover the act of filing a lawsuit, and they reveal little about the FHA's interaction with the First Amendment. To answer those questions, it is necessary to turn to cases that address the right to sue in other statutory settings.

Accordingly, Part II discusses the ways in which courts have balanced the First Amendment's protection of litigation activity against the dictates of federal statutory schemes. In general, the Supreme Court has been very reluctant to interpret federal statutes as prohibiting litigation activity, with narrow exceptions. This reluctance is best illustrated by the so-called NoerrPennington doctrine in antitrust law. Yet Noerr-Pennington is not the only model of statutory immunity for litigation; the case law offers competing models, especially in labor law, that may be relevant to the Fair Housing Act. Part II concludes by examining the conflicting standards used by the courts in FHA cases.

Part III explains the inadequacy of the standards currently in use. Many courts assume that the Noerr-Pennington doctrine compels a single boundary between protected and unprotected litigation activity across all statutory contexts. Other courts, seeking an alternative to Noerr-Pennington, have stated that liability may be imposed upon litigants for filing lawsuits that pursue "illegal objectives." Part III argues that Noerr-Pennington is too narrow in the Fair Housing Act context, and that the "illegal objective" argument sweeps too broadly.

Finally, Part IV proposes a model for the actionability of state court lawsuits under the FHA, based on the concept of 
discriminatory intent and the tort of abuse of process. Representing a middle ground between the Noerr-Pennington and illegalobjective standards, the intent-based approach is consistent with the terms of the FHA-which prohibits certain actions taken because of race, handicap or other impermissible criteria-and with the First Amendment.

\section{The FaIR Housing ACT AND the UNDERLYING STATE COURT LAWSUIT}

A. The FHA's Interaction with Local Land-Use Rules and Decisions

The Fair Housing Act was enacted as Title VIII of the 1968 Civil Rights Act, in the words of one court, "to eliminate all traces of discrimination within the housing field." ${ }^{\text {s }}$ The core provisions of the FHA as originally enacted make it unlawful to refuse to rent or sell real property, or otherwise to make property unavailable, or to discriminate in terms and conditions, on the basis of race, color, religion, or national origin..$^{9}$ The FHA also contains an "anti-intimidation" provision; in language similar to that of several other federal statutes, $\S 3617$ of the Act provides that "[i]t shall be unlawful to coerce, intimidate, threaten, or interfere with" anyone attempting to enjoy the rights ensured by the statute. ${ }^{10}$ The FHA explicitly preempts state and local rules that conflict with it: "[A]ny law of a State, a political subdivision, or other such jurisdiction that purports to require or permit any action that would be a discriminatory housing practice under this subchapter shall to that extent be invalid."11

In 1988, Congress amended the FHA to cover additional protected groups, including "handicapped" persons. ${ }^{12}$ Congress

8 Marr $v$ Rife, 503 F2d 735, 740 (6th Cir 1974). See also the unanimous Supreme Court decision in Trafficante $v$ Metropolitan Life Insurance Co., 409 US 205, 211, 212 (1972) (The FHA implements a "policy that Congress considered to be of the highest priority," and the language of FHA is therefore to be accorded "a generous construction.").

942 USC $\S 3604$. The FHA was amended in 1974 to cover discrimination on the basis of sex. Pub L No 93-383, 88 Stat 729 (1974), codified at 42 USC $\S 3604$ (1994).

1042 USC $\$ 3617$. Compare, for example, the anti-intimidation provisions of the Civil Rights Act of 1964, 42 USC § 1971 (1994); 18 USC § 241 (1994); 42 USC § 1985(3) (1994); Title II of the Civil Rights Act of 1964, 42 USC $\S 2000 \mathrm{a}-2(\mathrm{~b})$ (1994); and the National Labor Relations Act, 29 USC $\$ 158$ (a)(1) (1994). The FHA also includes a criminally enforceable anti-intimidation provision, 42 USC $\S 3631$. For a brief discussion of the constitutionality of this provision, see text accompanying notes $35-38$.

1142 USC § 3615.

12 Fair Housing Amendments Act of 1988, Pub L No 100-430, 102 Stat 1619, codified at 42 USC $\S \S 3601$ et seq (1994). The FHA was expanded to cover discrimination based on 
amended the statute in part because it recognized that group homes for the handicapped often arouse opposition among local residents. ${ }^{13}$ The FHA defines "handicap" as a physical or mental impairment that substantially limits a person's major life activities. ${ }^{14}$ The amended FHA also provides that it shall be unlawful to refuse "to make reasonable accommodations in rules, policies, practices, or services, when such accommodations may be necessary to afford [a handicapped] person equal opportunity to use and enjoy a dwelling." 15 The combined effect of the preemption and reasonable-accommodations provisions is to place zoning ordinances that interfere with the housing rights of handicapped people under special scrutiny. The Report of the House Judiciary Committee provides additional evidence that the FHA was meant to apply to local land use policies: "The Committee intends that the prohibition against discrimination against those with handicaps apply to zoning decisions and practices."

Consistent with the text and history of the FHA, courts have repeatedly held that the statute trumps local zoning rules and decisions that conflict with it. ${ }^{17}$ Zoning laws that facially discriminate against handicapped individuals or others protected by the FHA are rare today; such laws are undoubtedly preempted. ${ }^{18}$ More commonly, courts have applied the FHA to invalidate

handicap and familial status (that is, status as a parent or other custodial person domiciled with children under the age of 18). 42 USC $\S 3602$. Although several of the relevant cases have arisen outside the handicap context, this Comment focuses on the handicap provisions of the FHA because many of the cases concerning neighborhood opposition and petitioning activity involve group homes for the handicapped.

${ }^{13}$ The House Judiciary Committee report noted that the Committee "intend[s] to prohibit special restrictive covenants or other terms or conditions, or denials of service because of an individual's handicap and which have the effect of excluding, for example, congregate living arrangements for persons with handicaps." HR Rep No 100-711, 100th Cong, 2d Sess 23 (1988), reprinted in 1988 USCCAN 2184.

1442 USC \& $3602(\mathrm{~h})$. It is well established that "handicapped" people under the FHA include recovering addicts (as long as they are not currently using and have no record of drug convictions), people with AIDS, and mentally and emotionally disturbed people. See, for example, United States $v$ Southern Management Corp, 955 F2d 914, 922-23 (4th Cir 1992) (participants in residential drug rehabilitation programs covered by FHA); Baxter $v$ City of Belleville, 720 F Supp 720, 728-30 (S D Ill 1989) (people with AIDS); Marbrunak, Inc. $v$ City of Stow, 974 F2d 43, 45 (6th Cir 1992) (mentally disabled people).

1542 USC \& $3604(\mathrm{f})(3)(\mathrm{B})$.

${ }^{16}$ HR Rep No 100-711 at 24 (cited in note 13).

17 For a detailed discussion of cases applying the FHA to zoning policies that affect recovery homes, see Douglas E. Miller, Note, The Fair Housing Act, Oxford House, and the Limits of Local Control over the Regulation of Group Homes for Recovering Addicts, 36 Wm \& Mary L Rev 1467, 1482-98 (1995).

${ }^{18}$ See Horizon House Developmental Serv., Inc. $v$ Township of Upper Southampton, 804 F Supp 683, 700 (E D Pa 1992) (holding ordinance requiring one-thousand-foot 
zoning decisions that are the result of selective and discriminatory applications of facially neutral ordinances. ${ }^{19}$ Courts have also read the FHA to invalidate neutral zoning ordinances that have a disparate impact on protected groups ${ }^{20}$ and to require exemptions from zoning laws for handicapped dwellers in accordance with the FHA's reasonable-accommodations requirement. ${ }^{21}$

\section{B. The Edmonds Decision: The FHA's Broad Sweep Confirmed}

The Supreme Court's recent decision in City of Edmonds $v$ Oxford House, Inc. ${ }^{22}$ confirmed the broad sweep of the FHA with respect to local zoning codes. Oxford House established a group home for ten to twelve recovering alcoholics in a single-family neighborhood in Edmonds, Washington. The city cited the home for a violation of its zoning code, which defined "family" as "persons [without regard to number] related by genetics, adoption, or marriage, or a group of five or fewer [unrelated] persons." ${ }^{23} \mathrm{Ox}-$ ford House, which believes that its homes must contain between eight and twelve residents to be "financially and therapeutically viable," asked the city to make a "reasonable accommodation" permitting it to remain in the single-family zone. ${ }^{24}$ When the city refused, Oxford House sued under the FHA. In its defense, the city pointed to a provision of the FHA that excludes from the statute's preemptive reach "any reasonable local, State, or Federal restrictions regarding the maximum number of occupants permitted to occupy a dwelling."25

The Court, in a 6-3 decision, held that the exemption for reasonable occupancy restrictions referred to rules that place a cap on occupants, usually on a per-room or per-square-foot basis,

spacing between group homes facially discriminatory). But see Familystyle of St. Paul, Inc. $v$ City of St. Paul, 923 F2d 91, 95 (8th Cir 1991) (upholding a similar ordinance).

19 See, for example, Oxford House, Inc. $v$ Town of Babylon, 819 F Supp 1179, 1184-85

(E D NY 1993) (enforcement of facially neutral zoning ordinance against recovering alcoholics violates $\mathrm{FHA}$ ).

${ }_{20}$ See, for example, Huntington Branch, NAACP v Town of Huntington, 844 F2d 926, 937-39 (2d Cir 1988) (city's restrictive zoning scheme held to violate FHA due to segregative effect); Oxford House-Evergreen $v$ City of Plainfield, 769 F Supp 1329, 1343-44 (D NJ 1991) (zoning ordinance held invalid because it had disparate impact on recovering addicts).

${ }^{21}$ See, for example, United States $v$ Village of Marshall, 787 F Supp 872, 878-79 (W D Wis 1991) (holding that city's failure to exempt group home from zoning ordinance violated FHA).

22115 S Ct 1776 (1995).

${ }^{23}$ Id at 1778-79, citing Edmonds Community Development Code $\S 21.30 .010$ (1991).

24 Edmonds, 115 S Ct at 1779.

${ }_{25}$ Id at 1778 , citing 42 USC $\S 3607(b)(1)$. 
in order to protect health and safety by preventing overcrowding. ${ }^{26}$ It rejected the notion that a definition of "family" inherent in the designation of a single-family zoning district constitutes a reasonable occupancy restriction within the meaning of the FHA's exemption. The Court pointed out that the definition of "family" in the Edmonds zoning code did not answer the question, "What is the maximum number of people who may live in one house in this neighborhood?" because the code allowed an unlimited number of related persons to cohabitate, while capping the number of unrelated cohabitants at five. ${ }^{27}$ Having determined that the zoning code was not exempt from coverage, the Court remanded the case to the lower court to determine whether Edmonds's application of the zoning code was indeed invalid under the FHA. ${ }^{28}$

Thus it appears that Congress intended the FHA to be read broadly in relation to local rules and ordinances, invalidating them where necessary to achieve its purposes. As Part III describes, this expansive reading stands in contrast to the Court's treatment of other federal statutes, such as its presumption against construing the Sherman Act to impinge upon the laws and policies of the states. ${ }^{29}$

\section{The FHA's Interaction with the First Amendment}

The specific question of whether the filing of a state court lawsuit can represent grounds for liability under the FHA is not directly addressed in that statute's text or legislative history. The FHA's statement of purpose tersely (and unhelpfully) declares that "[i]t is the policy of the United States to provide, within

${ }^{26}$ The $\S 3607(\mathrm{~b})(1)$ exemption was enacted simultaneously with the inclusion of "familial status" as a protected category under the FHA. As the Court noted, the primary motive behind the exemption was to allay the fears of landlords that they would be forced to allow large families to crowd into small apartments in violation of safety codes. Edmonds, $115 \mathrm{~S} \mathrm{Ct}$ at $1782 \mathrm{n} 9$.

${ }^{27}$ Edmonds, $115 \mathrm{~S}$ Ct at 1782-83.

${ }^{28}$ Congress may be inclined to read the FHA more narrowly than the Edmonds majority. The recently enacted Omnibus Consolidated Rescissions and Appropriations Act of 1996 prevents HUD lawyers from pursuing the type of claim made by Oxford House in Edmonds. Pub L No 104-134, § 224, 110 Stat 1321.

${ }_{29}$ See Parker $v$ Brown, 317 US 341, 351-52 (1943) (holding that Sherman Act does not apply to anticompetitive restraints imposed by states as acts of government); City of Columbia v Omni Outdoor Advertising, Inc., 499 US 365, 384 (1991) (Petitioning for favorable zoning ordinance cannot constitute an antitrust violation in light of Parker's commitment to federalism.). 
constitutional limitations, for fair housing throughout the United States."30

There are clues, however, that suggest that Congress intended the FHA to outlaw at least some discriminatory actions that involve litigation or other expressive activity. First, the legislative history of the FHA indicates that Congress intended it to prohibit discriminatory evictions. ${ }^{31}$ Evictions often involve resort to the courts as part of summary process, yet Congress appeared content to allow this kind of litigation to be subject to challenge under the FHA. The statute's accompanying regulations also indicate that discriminatory evictions are covered. ${ }^{32}$ Courts have had little difficulty finding that evictions (or even threats of eviction), when based on impermissible criteria, are actionable under the FHA, even when the eviction is otherwise legally permissible. ${ }^{33}$ Similarly, courts have held, without any apparent First Amendment concerns, that the FHA may prohibit the bringing of a discriminatory mortgage foreclosure action. ${ }^{34}$

Several of the FHA's provisions have been upheld against First Amendment challenges in cases not involving the regulation of petitioning activity. Of these, the most relevant is $\S 3631,{ }^{35}$ the FHA's criminally enforceable anti-intimidation provision, which parallels $\S 3617,{ }^{36}$ the civil anti-intimidation provision at issue in most of the cases involving actionability of state court lawsuits. Section 3631 imposes criminal penalties upon anyone who "by force or threat of force willfully injures, intimidates or interferes with" a member of a protected class attempting to enjoy the housing rights guaranteed by the FHA. ${ }^{37}$ Circuit courts have upheld $\S 3631$ against constitutional challenges, reasoning

30 42 USC $\$ 3601$ (emphasis added).

31 "Depriving [recovering addicts] of housing, or evicting them, would constitute irrational discrimination that may seriously jeopardize their continued recovery." HR Rep No 100-711 at 22 (cited in note 13) (emphasis added).

${ }^{32} 24 \mathrm{CFR}$ \& 100.60(b)(5) (1995) (forbidding landlords from "[e]victing tenants because of their race, color, religion, sex, handicap, familial status, or national origin or because of the race, color, religion, sex, handicap, familial status, or national origin of a tenant's guest").

${ }^{33}$ See, for example, Woods-Drake $v$ Lundy, 667 F2d 1198, 1202 (5th Cir 1982); Gorski $v$ Troy, 929 F2d 1183, 1189-90 (7th Cir 1991); HUD v Gutleben, 1994 WL $441981 * 10$ (HUD ALJ).

${ }_{34}$ Harper $v$ Union Savings Association, 429 F Supp 1254, 1257-59 (N D Ohio 1977) (racially motivated foreclosure action may violate FHA's fair lending provisions); Lindsey v Modern American Mortgage Corp, 383 F Supp 293, 294 (N D Tex 1974) (same).

${ }^{35} 42$ USC $\S 3631$.

${ }^{36} 42$ USC $\S 3617$.

${ }^{37} 42$ USC § 3631(a). 
that the provision regulates harmful conduct and only incidentally sweeps speech within its ambit. ${ }^{38}$ The provision of the FHA that regulates discriminatory advertising has also come under First Amendment attack, yet no court has squarely held the provision unconstitutional. ${ }^{39}$

\section{Statutory REgulation of the Right to SuE}

Although the Supreme Court has repeatedly held that litigation is a protected activity under the First Amendment, the precise nature and extent of the right to sue remain unclear. In the landmark 1963 case of NAACP $v$ Button, the Court declared that the First Amendment "protects vigorous advocacy, certainly of lawful ends, against government intrusion." ${ }^{\text {"40 }}$ It consequently held that the NAACP's solicitation, organizing, and litigation activities constituted "a form of political expression" insulated from prohibition by the state. ${ }^{41}$ In subsequent cases, relying heavily on the right of association, the Court struck down several state statutes that regulated the lawyering activities of unions. ${ }^{42}$

${ }^{38}$ See United States $v$ Hayward, 6 F3d 1241, 1250-52 (7th Cir 1993), cert denied, 114 S Ct 1369 (1994) (holding that application of $\S 3631$ to cross burning does not violate First Amendment); United States v J.H.H., 22 F3d 821, 825 (8th Cir 1994) (rejecting First Amendment challenge to $\S 3631$ ).

${ }^{39}$ For cases involving 42 USC § 3604(c), see Ragin $v$ New York Times Co., 923 F2d 995, 1002-05 (2d Cir 1991) (holding that $\$ 3604$ (c) does not hinder protected commercial speech). But see Housing Opportunities Made Equal, Inc. $v$ Cincinnati Enquirer, Inc., 943 F2d 644, 646-53 (6th Cir 1991) (FHA may not constitutionally reach long-term pattern of publishing real estate advertisements with white-only models). On the FHA's advertising provisions, see generally Robert G. Schwemm, Housing Discrimination: Law and Litigation \& 15 (Clark Boardman Callaghan 1990 \& Supp 1995).

40371 US 415, 429 (1963). This Comment treats the filing of a lawsuit under the broad rubric of "the First Amendment," without attempting to specify which clause of that Amendment protects the right to sue. At times the Supreme Court has stated that "filing a complaint in court is a form of petitioning activity" within the meaning of the Petition Clause. McDonald v Smith, 472 US 479, 484 (1985). At other times, however, the Court has treated litigation as a form of expression and assembly. See, for example, Button, 371 US at 429. In any event, the Court has often repeated that the freedoms of the press, speech, petition, and assembly are "cognate," and must be afforded comparably strong protection: "All these, though not identical, are inseparable." Thomas $v$ Collins, 323 US 516,530 (1945).

41 Button, 371 US at 429.

42 Brotherhood of Railroad Trainmen $v$ Virginia State Bar, 377 US 1, 8 (1964) (invalidating state court injunction against union program of attorney referrals in worker injury cases); United Mine Workers of America v Illinois Bar Association, 389 US 217, 225 (1967) (invalidating injunction preventing union from retaining a lawyer to pursue workers' compensation claims on behalf of members); United Transportation Union $v$ State Bar of Michigan, 401 US 576, 586 (1971) (lifting injunction preventing union from recommending contingent-fee attorneys to members). 
Button and its progeny leave several questions unanswered, however. First, some of the Court's statements strongly suggest that litigation to vindicate political rights merits greater protection than litigation in pursuit of purely economic interests. ${ }^{43}$ Such a distinction would parallel the Court's free speech jurisprudence, which has granted stronger protection to political than commercial speech. ${ }^{44}$ Second, the extent to which even civil rights litigation enjoys only qualified First Amendment protection compared to "pure speech" is unclear. Some commentators, for example, read the Button line of cases to hold that the Constitution only ensures access to judicial fora when the right to petition is conjoined with other First Amendment guarantees, such as the right to assembly. ${ }^{45}$ Third, the Court has not fashioned a clear test to determine what sorts of state interests are compelling enough to permit legislative regulation of litigation activity.

In short, the Button line of cases does not clearly delineate the contours of the right to sue. Moreover, those cases concerned challenges to the constitutionality of state statutes expressly regulating litigation activity. The Court has spoken more fully to the right-to-sue issue in the course of interpreting broad federal statutes that, like the FHA, could be read to cover the act of filing a lawsuit. Of these, the best known and most relevant come from the field of antitrust law.

${ }^{43}$ See Button, 371 US at 429 ("In the context of NAACP objectives, litigation is not a technique of resolving private differences; it is a means for achieving the lawful objectives of equality of treatment ... ."). Compare In re Primus, 436 US 412, 431 (1978) (solicitation by ACLU attorneys protected by First Amendment because ACLU "engages in litigation as a vehicle for effective political expression and association, as well as a means of communicating useful information to the public"), with its companion case, Ohralik $v$ Ohio State Bar Association, 436 US 447, 468 (1978) (solicitation of personal injury clients not protected by First Amendment). See also Maximilian A Grant, Comment, The Right Not to Sue: A First Amendment Rationale for Opting Out of Class Actions, $63 \mathrm{U}$ Chi L Rev 239, 264-67 (1996).

${ }_{44}$ Compare Primus, 436 US at 432 (ban on ACLU solicitation subjected to the "exacting scrutiny applicable to limitations on core First Amendment rights"), quoting Buckley $v$ Valeo, 424 US 1, 44-45 (1976), with Ohralik, 436 US at 456 (comparing solicitation by personal injury lawyer to commercial speech, which occupies a "subordinate position in the scale of First Amendment values"). But see United Mine Workers, 389 US at 223 (protection of litigation activity not limited to causes "bound up with political matters of acute social moment").

45 Julie M. Spanbauer, The First Amendment Right to Petition Government for a Redress of Grievances: Cut from a Different Cloth, 21 Hastings Const L Q 15, 45 (1993); Kara Elizabeth Shea, San Filippo v. Bongiovanni: The Public Concern Criteria and the Scope of the Modern Petition Right, 48 Vand L Rev 1697, 1707-08 (1995). 
A. The Noerr-Pennington Doctrine

The most extensive examination by the Supreme Court of Congress's power to restrict the right to sue is the NoerrPennington line of cases. Despite the fact that Noerr-Pennington is an antitrust doctrine, several courts have relied on it to determine the extent to which the Fair Housing Act reaches state court lawsuits. Although Part III argues that Noerr-Pennington has no special precedential force in the FHA context, the doctrine provides a good analytical starting point.

The doctrine stems from three Supreme Court cases: Eastern R.R. Presidents Conference $v$ Noerr Motor Freight, Inc. ${ }^{46}$ United Mine Workers of America $v$ Pennington, ${ }^{47}$ and California Motor Transport Co. $v$ Trucking Unlimited. ${ }^{48}$ In Noerr, trucking companies sued several railroads under the Sherman Act, ${ }^{49}$ claiming that by launching a campaign of political advertisements and lobbying in support of antitrucking laws, the railroads sought to establish a monopoly over the long-haul freight industry. The Court held that the Sherman Act does not prohibit people from combining in an attempt to persuade the legislative or executive branches to take anticompetitive action..$^{50}$ Pennington extended Noerr's protection to efforts to persuade administrative agencies, ${ }^{51}$ and-crucially for present purposes-California Motor Transport extended it yet again to include litigation activity. ${ }^{52}$

Commentators have disagreed about the extent to which the Noerr-Pennington holdings declare a First Amendment principle that is compulsory outside the antitrust setting. ${ }^{53}$ The Supreme
16365 US 127 (1961).
47381 US 657 (1965).
48404 US 508 (1972).
415 USC $\S \S 1,2$ (1958).
so Noerr, 365 US at 136.
51 Pennington, $381 \mathrm{US}$ at 670.
52 California Motor Transport, 404 US at 510-11. The Court concluded:

[1]t would be destructive of rights of association and of petition to hold that groups with common interests may not, without violating the antitrust laws, use the channels and procedures of state and federal agencies and courts to advocate their causes and points of view respecting resolution of their business and economic interests visà-vis their competitors.

Id.

53 For an argument that Noerr-Pennington immunity for petitioning activity should be coterminous with First Amendment immunity, see Daniel R. Fischel, Antitrust Liability for Attempts to Influence Government Action: The Basis and Limits of the NoerrPennington Doctrine, $45 \mathrm{U}$ Chi L Rev 80 (1977). Another commentator has argued that 
Court sidestepped the issue by expressly declining to rule on the Noerr defendants' claim that their lobbying activity was protected by the First Amendment. ${ }^{54}$ The Noerr Court did, however, invoke the First Amendment in the course of explaining its unwillingness to interpret the Sherman Act to prohibit petitioning activity, noting that "such a construction of the Sherman Act would raise important constitutional questions. The right of petition is one of the freedoms protected by the Bill of Rights, and we cannot, of course, lightly impute to Congress an intent to invade these freedoms." Transport stated flatly that the Sherman Act, if interpreted to make all anticompetitive litigation activity illegal, would be unconstitutional. $^{56}$ It did not, however, declare that the First Amendment places litigation activity completely beyond the reach of the antitrust laws. Indeed, the Court held that the antitrust violations alleged by the plaintiffs-the filing of state and federal lawsuits by trucking companies-fell within the so-called "sham" exception to Noerr-Pennington immunity and were thus potentially subject to antitrust liability. ${ }^{57}$

\section{B. The "Sham" Exception}

The sham exception stems from dicta in the Noerr opinion. The Noerr Court, while holding that the defendants' lobbying and publicity activities did not rise to the level of antitrust violations, noted that petitioning activity could conceivably violate the Sherman Act, the First Amendment notwithstanding: "There may be situations in which a publicity campaign, ostensibly directed toward influencing governmental action, is a mere sham to cover what is actually nothing more than an attempt to interfere di-

the doctrine is a matter of statutory interpretation, and thus liability for litigation should be approached differently in different statutory contexts. See Robert A. Zauzmer, Note, The Misapplication of the Noerr-Pennington Doctrine in Non-Antitrust Right to Petition Cases, 36 Stan L Rev 1243 (1984).

${ }^{54}$ Noerr, 365 US at $132 \mathrm{n} 6$.

${ }_{55}$ Id at 138. At the level of pure statutory interpretation, the Noerr Court relied on the observation that there was an "essential dissimilarity between an agreement jointly to seek legislation or law enforcement and the agreements traditionally condemned by" the Sherman Act. Id at 136. Legislative history also supports the Noerr holding. Senator Sherman, the main sponsor of the law, stated that it "does not interfere in the slightest degree with voluntary associations made to affect the public opinion to advance the interests of a particular trade or association." S 1, 51st Cong, 1st Sess (Mar 24, 1890), in 21 Cong Rec S2562 (Mar 24, 1890).

${ }_{56} 404$ US at 510-11.

57 Id at 511-12. 
rectly with the business relationships of a competitor and the application of the Sherman Act would be justified." 58

This exception was elucidated further in California Motor Transport. There, the Court held that the Sherman Act reaches litigants who file lawsuits not to obtain the judicial relief they ostensibly seek, but "to bar their competitors from meaningful access to adjudicatory tribunals and so to usurp that decisionmaking process." Such "strategic" lawsuits enjoy no immunity from antitrust liability. Thus, it is possible to read California Motor Transport as declaring a narrow, "access-barring" sham exception: litigation is subject to antitrust liability only if the purpose and effect of the litigation is to exclude the other side from petitioning the government. Alternatively, one can read the opinion as labelling a "sham" any lawsuit not sincerely aimed at obtaining its prayed-for relief, regardless of its effect on access to the courts. ${ }^{60}$

The Court recently explored-and narrowed-the scope of the sham exception in Professional Real Estate Investors, Inc. $v$ Columbia Pictures Indus., Inc. ${ }^{61}$ The Court rejected a definition of "sham" based solely on the litigant's subjective intent in bringing the allegedly anticompetitive lawsuit. Instead, it outlined a two-part definition of sham litigation. "First, the lawsuit must be objectively baseless in the sense that no reasonable litigant could realistically expect success on the merits." ${ }^{\text {"62 }}$ Second, the plaintiff must have brought the suit in order to interfere with a competitor's business through the process as opposed to the outcome of court action. ${ }^{63}$ If both of these requirements are met, the lawsuit is a sham and subject to possible liability under the Sherman Act. The Court based this two-part test on the standards governing the common law tort of malicious prosecution. ${ }^{64}$

58 Noerr, 365 US at 144.

59 California Motor Transport, 404 US at 512.

60 The Court also stated that a "pattern of baseless, repetitive claims" could constitute a Sherman Act violation. Id at 513. Compare Vendo Co. $v$ Lektro-Vend Corp, 433 US 623, 644 (1977) (Blackmun concurring) (arguing that a pattern of baseless, repetitive claims should be required before a federal court may enjoin state proceedings under Clayton Act).

62508 US 49 (1993). See also City of Columbia v Omni Outdoor Advertising, Inc., 499 US 365, 384 (1991) (lobbying for favorable zoning ordinance exempted from antitrust liability).

${ }^{62}$ Professional Real Estate Investors, 508 US at 60.

63 Id at 61.

64 Id at 61-62. In fact, as the Court noted, malicious prosecution is technically limited to the criminal context; the equivalent tort on the civil side is known inelegantly as "wrongful civil proceedings." Id at 62 n 7, citing Restatement (Second) of Torts, $\S 674$ 
What is left after Professional Real Estate Investors is a very narrow sham exception-and, consequently, broad antitrust immunity for litigation activity.

\section{Bill Johnson's and the Illegal-Objective Standard}

In 1983, the Supreme Court considered the applicability of the Noerr-Pennington principle in a nonantitrust setting. ${ }^{65} \mathrm{~A}$ waitress at Bill Johnson's Restaurant, who claimed she was fired for trying to organize a union, picketed her former employer and distributed leaflets. The restaurant's owners sued her in state court, charging her with harassing customers, blocking access to the restaurant, threatening public safety, and distributing libelous information. ${ }^{66}$ She in turn filed a charge with the National Labor Relations Board ("NLRB"), alleging that the employer's suit was retaliatory and therefore an unfair labor practice under the National Labor Relations Act ("NLRA"). ${ }^{67}$ The NLRB agreed, and ordered Bill Johnson's to withdraw its state court suit.

The Supreme Court reversed, holding that a state court lawsuit may not be enjoined as an unfair labor practice under the NLRA, even if filed for retaliatory purposes, unless it lacks a reasonable basis in fact or law. ${ }^{68}$ The court noted California Motor Transport's solicitude for the right to petition, and concluded that "[w]e should be sensitive to these First Amendment values in construing the NLRA in the present context."

Again, however, the right of access to the courts was not held to be absolute. Instead, the Court announced three exceptions to its principle of labor law immunity for litigation. First, as in Noerr-Pennington's sham exception, the Court held that a baseless and retaliatory state suit could be enjoined under the NLRA. ${ }^{70}$ Second, the Court explained that if the state suit proceeds and the employer loses, the NLRB may step in and award costs, or other appropriate relief, to the prevailing party if it finds

(1977).

${ }_{65}$ Bill Johnson's Restaurants, Inc. v NLRB, 461 US 731 (1983).

66 Id at 734 .

6729 USC $\S \S 158(a)(1),(a)(4)(1994)$.

68 Bill Johnson's, 461 US at 748-49.

69 Id at 741.

${ }^{70}$ Id at $743-44$. 
the lawsuit was retaliatory. ${ }^{71}$ Third, and most important for present purposes, the Court suggested another exception:

It should be kept in mind that what is involved here is an employer's lawsuit that the federal law would not bar except for its allegedly retaliatory motivation. We are not dealing with a suit that is claimed to be beyond the jurisdiction of the state courts because of federal-law preemption, or a suit that has an objective that is illegal under federal law. Petitioner concedes that the Board may enjoin these latter types of suits. ${ }^{72}$

The circuit courts have seized on the "illegal objective" exception in upholding NLRB cease-and-desist orders enjoining state court lawsuits. For example, the D.C. Circuit held in International Longshoremen's and Warehousemen's Union $v$ NLRB that a union's contract-based state court challenge to an award granted by the NLRB was illegal under the NLRA. ${ }^{73}$ Because an award by the NLRB preempts any contrary contract claim, the court held that the union's state law case-no matter how reasonable or well intentioned-fell within the illegal-objective exception contemplated by Bill Johnson's. ${ }^{74}$ Similarly, in Chauffeurs, Teamsters, and Helpers Local $776 v$ NLRB, the Third Circuit held that a federal suit that had been initiated in order to circumvent the NLRB's authority sought an illegal objective and could be enjoined. ${ }^{75}$

Judge Easterbrook of the Seventh Circuit expounded a version of the illegal-objective argument in the antitrust context in Premier Elec. Constr. Co. v National Elec. Contractors Ass'n, Inc. ${ }^{76}$ In Premier, an electrical contractor argued that it was entitled to treble damages based on the costs of defending lawsuits that sought to enforce an allegedly anticompetitive provision in a collective bargaining agreement. The court conceded that the underlying lawsuits had some objective basis, but nonetheless

"I Id at 747. The Court did not indicate whether a voluntarily dismissed state suit can form a basis for damages. Justice Brennan's concurrence suggests that the NLRB should retain discretion to determine whether a withdrawn complaint constituted an unfair labor practice. Id at $753 \mathrm{n} 3$ (Brennan concurring).

72 Bill Johnson's, 461 US at 737 n 5 (emphasis added).

73 884 F2d 1407, 1414 (DC Cir 1989).

74 Id.

${ }^{75} 973$ F2d 230, 235-36 (3d Cir 1992).

76 814 F2d 358, 371-76 (7th Cir 1987). 
rejected Noerr-Pennington immunity. Judge Easterbrook concluded:

The antitrust laws allow people to ask the government for a monopoly, and they allow them to keep what they get. A request for something that, if granted, is lawful, is also lawful. A request for something that, if granted, is unlawful, is also unlawful. ... [The underlying lawsuit in this case] was not a petition for a favorable rule of law; it was not an effort to implement an existing rule of law; it was an unvarnished effort to enforce a private price-fixing agreement. The first amendment does not protect efforts to enforce private cartels, in court or out. ${ }^{77}$

\section{Existing Standards Applied to the Fair Housing Act}

Several courts have directly tested whether liability can be imposed under the FHA for the filing and prosecution of a state court lawsuit. ${ }^{78}$ Most of these courts have adopted either the Noerr-Pennington doctrine or some variant of the illegal-objective approach. ${ }^{79}$ However, no coherent doctrine has developed in this area. These cases demonstrate that courts need guidance in

77 Id at 376. For other examples of the illegal-objective argument, see Mayer $v$ Wedgewood Neighborhood Coalition, 707 F2d 1020, 1023 (9th Cir 1983) ("While normally protected by the first amendment, the invocation of administrative or judicial proceedings may be tortious and actionable if employed for a purpose that is unlawful and is other than and in addition to the goal sought openly in the proceeding itself."); Wright $v$ DeArmond, 977 F2d 339, 347 (7th Cir 1992) (The First Amendment "does not extend a right to use the courts for fraudulent or unlawful purposes.").

${ }^{78}$ The plaintiff may also ask a federal court to enjoin the state suit. The case law on injunctions is divided. See, for example, Casa Marie, Inc. $v$ Superior Court, 988 F2d 252, 270 (1st Cir 1993) (denying injunction against enforcement of state court order closing home for handicapped seniors as a result of restrictive covenant). But see Martin $v$ Constance, 843 F Supp 1321, 1323 n 1 (E D Mo 1994) (rejecting Casa Marie analysis where plaintiffs seeking injunction had not been permitted to intervene in state suit); Tizes $v$ Curcio, 1995 US Dist LEXIS 11368, *5-7 (N D II) (rejecting abstention arguments of state court plaintiffs who allegedly filed discriminatory zoning appeals).

${ }^{79}$ An exception is United States $v$ Scott, 788 F Supp 1555 (D Kan 1992), the first case in which the government argued that the filing of a lawsuit violated the FHA. In Scott, the district court held that a state court action to enforce a restrictive covenant against a group home for the mentally retarded was illegal under the FHA. Relying on legislative history indicating that the FHA was intended to reach the enforcement of discriminatory restrictive covenants, the court concluded that the defendants violated $\S \S 3604$ and 3617 . Id at 1562-63. No First Amendment defense was raised in the case. See United States Commission on Civil Rights, The Fair Housing Amendments Act of 1988: The Enforcement Report 132 (US GPO 1994). See also Northside Realty Associates, Inc. $v$ Chapman, $411 \mathrm{~F}$ Supp 1195, 1199-1200 (N D Ga 1976) (stating, without First Amendment discussion, that bringing of state court lawsuit may violate $\S 3617$ ). 
weighing the right to sue against the provisions of the Fair Housing Act. ${ }^{80}$

Of the decisions adopting the Noerr-Pennington analysis, United States $v$ Robinson is the most detailed in its reasoning. ${ }^{81}$ The facts of the case should be familiar from this Comment's introductory hypothetical: Marilyn Eichler purchased a home in New Haven's affluent Ronan-Edgehill neighborhood, and planned to move in with her adopted and foster children, all of whom were handicapped. ${ }^{82}$ Neighbors filed suit in state court, arguing that Eichler's proposed use violated the single-family zoning code. Eichler responded by filing a complaint of housing discrimination with HUD; after the government began investigating the neighbors' activities, they dropped their state suit. ${ }^{83}$

The government then filed a claim in federal court under $\S \S$ 3604 and 3617 of the FHA, alleging that the filing of the state court suit discriminated against the Eichlers on the basis of familial status and handicap. The neighbors moved to dismiss on First Amendment grounds. A magistrate judge recommended denial of the motion, holding Noerr-Pennington inapplicable: "The fundamental ideals and aims of the two areas of the law-antitrust and civil rights-vary so widely that the mechanistic application of a doctrine from one area to the other would constitute an injustice." 84

The district court disagreed and dismissed the complaint. While the court agreed that the Noerr-Pennington standard was not constitutionally mandated, it adopted that doctrine's reasoning, including the narrow sham exception. It held that the neighbors' zoning action was not baseless as a matter of state law, and was therefore protected by the First Amendment. ${ }^{85}$ The Court rejected the illegal-objective argument, reasoning that "whether the defendants' lawsuit sought an illegal objective de-

so A separate line of cases addresses whether the state court defendant may remove the allegedly discriminatory action to federal court. See, for example, Sofarelliv Pinellas County, 931 F2d 718, 724 (11th Cir 1991) (allowing removal under 28 USC $\S 1443(1)$ where state court lawsuit violated movant's FHA rights on the basis of race); Robinson $v$ Eichler, 795 F Supp 1253, 1258 (D Conn 1992) (denying removal under § 1443(1) where foster home's FHA defense did not allege racial discrimination).

${ }^{81}$ Fair Housing-Fair Lending (P-H) II 15,979 (D Conn 1995).

82 Id II 15,979 at $15,979.1$.

83 Id II 15,979 at 15,979.2.

o4 United States $v$ Robinson, Fair Housing-Fair Lending (P-H) II 15,881 at 15,881.5

(D Conn 1993) (magistrate's recommended ruling).

\&s Robinson, Fair Housing-Fair Lending (P-H) II 15,979 at 15,979.11 to 15,979.12. 
pends on the lawsuit's legal merits, ${ }^{, 86}$ which could only be determined in the state court proceeding itself.

The application of the illegal-objective approach in the FHA context is exemplified by the district court opinion in LeBlancSternberg $v$ Fletcher ${ }^{87}$ A group of Orthodox Jews in Ramapo, New York alleged that local residents, in seeking to incorporate as the self-governing Village of Airmont, were motivated by a discriminatory intent to enact exclusionary zoning ordinances. They claimed that the residents' activity in petitioning for incorporation violated the $\mathrm{FHA}^{88}$ The Court cited Noerr-Pennington, but relied on the illegal-objective argument in holding that the First Amendment did not bar the plaintiffs' claim:

Discrimination through the exercise of government power is illegal, to state the obvious. It is one thing to make use of a petition to achieve legitimate, though adverse, goals. It is quite another to use a legitimate process for illegal purposes. ... Taking the plaintiffs' allegations of defendants' motives as true, we are not prepared to conclude that defendants' conduct is protected by the first amendment. ${ }^{89}$

${ }^{86}$ Id II 15,979 at $15,979.7$. For another case adopting a Noerr-Pennington analysis, see Weiss $v$ Willow Tree Civic Association, 467 F Supp 803 (S D NY 1979), which involved a claim under 42 USC $\S 1983$ rather than the FHA. The court, relying on California Motor Transport, held that the First Amendment protected the right of a residents' organization in Ramapo, New York, to oppose the development of an Orthodox Jewish housing complex through zoning appeals, complaints to a state agency, and other concerted action. Id at 817-19. See also HUD $v$ Grappone, 1993 WL 388605, *8-9 (HUD ALJ) (holding state lawsuit not impermissibly retaliatory under FHA unless baseless as a matter of fact or state law).

${ }_{87} 781$ F Supp 261 (S D NY 1991), aff'd in part and rev'd in part on other grounds, 67 F3d 412 (2d Cir 1995).

Bs LeBlanc-Sternberg, $781 \mathrm{~F}$ Supp at 269,271 . The plaintiffs also asserted claims under other civil rights statutes. Id at 267-69.

89 Id at 266-67. For other applications of the illegal-objective argument, see Casa $\mathrm{Ma}$ rie, Inc. v Superior Court, 752 F Supp 1152, 1169 (D PR 1990), rev'd on jurisdictional grounds, 988 F2d 252 (1st Cir 1993) (holding that neighbors' restrictive covenant action against home for handicapped seniors violated FHA, even if motivated by legitimate concerns); United States $v$ Wagner, 1996 US Dist LEXIS 4148, *18-19 (N D Tex) (lawsuit against home for mentally retarded violates FHA on illegal-objective grounds). 


\section{Moving BeYoNd the CURRENT ALternatives}

\section{A. Noerr-Pennington Immunity is Not Constitutionally Compelled}

The Noerr-Pennington doctrine does not establish a First Amendment standard of immunity for litigation activity outside the antitrust setting. ${ }^{90}$ The Noerr and Pennington decisions were exercises in statutory rather than constitutional interpretation. ${ }^{91}$ To be sure, the Noerr Court interpreted the Sherman Act in light of constitutional concerns, and it construed the statute to avoid them. ${ }^{92}$ Yet what emerges from those decisions is a pronouncement as to the meaning of the antitrust laws, not of the Constitution. ${ }^{93}$ Indeed, some observers fault the NoerrPennington doctrine for granting broader Sherman Act immunity to anticompetitive petitioning than the First Amendment would confer of its own force. ${ }^{94}$ In any event, the First Amendment need not be read to protect litigation activity to the same extent in all contexts. ${ }^{95}$

90 See generally Zauzmer, Note, 36 Stan L Rev 1243 (cited in note 53).

91 The Court in California Motor Transport was more straightforward than in Noerr and Pennington in holding that the First Amendment rights of association and petition precluded regulation of nonsham lawsuits by the Sherman Act. 404 US at 510-11. But even this holding "could be taken as nothing more than a restatement of the Court's fear in Noerr that if the antitrust laws were construed to reach political activity, they might infringe the right to petition." Zauzmer, Note, $36 \mathrm{Stan} L$ Rev at 1252 (cited in note 53).

${ }^{22}$ Noerr, 365 US at 138. By applying the "canon of construction" that calls for avoidance of constitutional doubts, courts can adumbrate a hazy area around the boundary of constitutionality rather than declare clear constitutional rules. The use of the canon in the context of antitrust immunity has been criticized for precisely this reason. See David McGowan and Mark A. Lemley, Antitrust Immunity: State Action and Federalism, Petitioning and the First Amendment, 17 Harv J L \& Pub Policy 293, 298 (1994) ("The Court's avoidance tactic [in Noerr and other antitrust cases] has created doctrinal confusion.").

${ }^{23}$ See Coastal States Marketing, Inc. $v$ Hunt, 694 F2d 1358, 1364-65 (5th Cir 1983) ("Noerr was based on a construction of the Sherman Act. It was not a first amendment decision. While the Court's opinion in California Motor Transport stressed the first amendment underpinnings of petitioning immunity, we do not view that opinion as overruling Noerr's clear holding that the Sherman Act simply does not extend to joint efforts to influence government officials.") (citations omitted). See also Cow Palace, Ltd. $v$ Associated Milk Producers, Inc., 390 F Supp 696, 702 (D Colo 1975) (explaining that activities unprotected by the First Amendment may still enjoy Noerr-Pennington immunity).

r See McGowan and Lemley, 17 Harv J L \& Pub Policy at 300 (cited in note 92) ("The scope of petitioning immunity has been broader than would be justified by the First Amendment."); Fischel, $45 \mathrm{U}$ Chi L Rev at 106 (cited in note 53) ("The sham exception should be reinterpreted to encompass all petitioning activity which is unprotected by the first amendment.").

${ }^{9}$ See San Filippo v Bongiovanni, 30 F3d 424, 438 (3d Cir 1994) ("[T]he scope of the petition right depends upon the context in which the right is exercised ...."). 
Moreover, reading a Noerr-Pennington standard into the First Amendment would create unexpected and troubling results. For instance, such a broad reading of the First Amendment would render the traditional tort of abuse of process unconstitutional. ${ }^{96}$ To take another example, fee-shifting statutes constitute a kind of penalty for bringing legal action. Yet, as Judge Easterbrook noted in Premier, it would be farfetched to suggest that the First Amendment restricts the "loser-pays" remedy to sham lawsuits. ${ }^{97}$

B. The FHA Covers a Broader Range of Litigation Activity than the Antitrust Laws

To show that Noerr-Pennington is not constitutionally compelled is not to show that it has no relevance outside the antitrust setting. As Bill Johnson's indicates, the Noerr-Pennington rule, with its two-part sham test, can be transplanted to other statutory settings with relative ease.$^{98}$ In the context of a federal civil rights statute such as the FHA, however, NoerrPennington-type immunity is too broad. The FHA should subject to liability some, but not all, of the lawsuits that NoerrPennington would protect. This result follows for two reasons.

First, divergent visions of federalism underlie the antitrust laws and the civil rights laws. The antitrust laws embody an expansive view of federalism, which gives individual states broad latitude to establish their own economic policies. The state-action exception to the antitrust laws, first articulated in the 1943 case of Parker $v$ Brown, ${ }^{99}$ reflects Congress's willingness to permit the states to restrain trade, play favorites in the marketplace, and even conduct experiments in state socialism. The NoerrPennington doctrine facilitates this vision by insulating from antitrust liability all sincere private attempts at persuading the government to stack the economic deck. As the Supreme Court recently stated, "Parker and Noerr are complementary expressions of the principle that the antitrust laws regulate business, not politics; the former decision protects the States' acts of governing, and the latter the citizens' participation in government." ${ }^{\prime 100}$ By contrast, civil rights laws from the Reconstruction

96 See text accompanying note 115 .

97 Premier, 814 F2d at 373 . The court stated further that the trebling of fees and costs makes no constitutional difference. Id.

${ }^{98}$ See text accompanying note 69.

99 317 US 341, 351 (1943).

100 City of Columbia v Omni Outdoor Advertising, Inc., 499 US 365, 383 (1991). 
period onward represent a break with traditional notions of federalism. These statutes, along with the Fourteenth Amendment, refashion the federal-state relationship. They govern the conduct of public as well as private actors. ${ }^{101}$ In particular, they preclude state instrumentalities, including state courts, from using their offices to endorse or facilitate discriminatory private preferences. ${ }^{102}$

Second, Noerr-Pennington immunity for exclusionary lawsuits would not adequately protect the housing rights safeguarded by the FHA. As the magistrate judge in Robinson pointed out, the right of handicapped homeseekers to live peacefully in a neighborhood may be destroyed permanently by the economic and reputational expense of defending a single lawsuit, even if that lawsuit ultimately fails. ${ }^{103}$ A Noerr-Pennington standard would insulate state court plaintiffs from liability as long as their claims had some colorable basis in state law, even if their decision to sue was based entirely on the homeseekers' handicapped status. Considering the financial and nonfinancial costs of defending a lawsuit, such a permissive standard would effectively expose some handicapped and other would-be residents to denials of housing based exclusively on their protected status under the FHA.

Yet some might argue that Noerr-Pennington immunity is sufficient in the fair housing context, precisely because of the FHA's broad preemptive scope. The argument runs as follows: a discriminatory state court zoning suit will be preempted by the FHA and will by definition lack a legal basis; it may therefore be penalized as a "sham." While attractive in theory, this argument

Indeed, Noerr cites Parker in support of its conclusion that petitioning the government does not violate the Sherman Act. Noerr, 365 US at 137 n 17.

${ }^{101}$ See, for example, City of Cleburne v Cleburne Living Center, Inc., 473 US 432, 44750 (1985) (Fourteenth Amendment prohibits municipality from requiring special use permit for mentally retarded group home.); United States v City of Parma, 661 F2d 562, 571-72 (6th Cir 1981) (FHA applies to states and political subdivisions as well as to individuals.).

102 See, for example, United States $v$ Yonkers Board of Education, 837 F2d 1181, 121826 (2d Cir 1987) (holding city liable under FHA and Equal Protection Clause for segregation in housing, even if segregation reflects citizens' preferences).

103 United States $v$ Robinson, Fair Housing-Fair Lending (P-H) II 15,881 at 15,881.6 (D Conn 1993) (magistrate's recommended ruling). To be sure, this argument could be made in the Sherman Act context as well: a single predatory lawsuit may well have serious anticompetitive effects. See McGowan and Lemley, 17 Harv J L \& Pub Policy at 365-66 (cited in note 92). Again, however, the federalism argument makes the difference. In enacting the antitrust laws, Congress was content to allow state adjudicative proceedings to produce anticompetitive outcomes. The sweep of the FHA with respect to state instrumentalities is broader. 
would likely fail in practice. Consistent with Noerr-Pennington, courts are likely to ask simply whether the underlying suit had any merit as a matter of state law, and ignore the preemption question. Moreover, a Noerr-Pennington standard could immunize a preempted lawsuit brought with some degree of good faith, even if the state court plaintiffs' motives were primarily discriminatory.

Certainly the Noerr-Pennington doctrine reaches the correct result in denying First Amendment protection to lawsuits lacking a reasonable basis in law or fact, ${ }^{104}$ yet the sham exception is too narrow in the fair housing context. Some state lawsuits that are not shams by Noerr-Pennington standards may still run afoul of federal civil rights laws, and of the FHA in particular.

\section{The Mllegal-Objective Model is Overbroad}

The Bill Johnson's case suggests a second model for the actionability of state court lawsuits under the FHA: lawsuits that seek "an objective that is illegal under federal law" may be subject to liability. At first glance, the preceding discussion of the different visions of federalism that underlie the antitrust and civil rights laws seems to support the illegal-objective standard. Governments (including state governments) may legally restrain trade and even create monopolies. Yet governments may not legally discriminate in housing in ways that violate the FHA. Arguably, then, the state court plaintiff seeking an exclusionary interpretation of a zoning ordinance is seeking an illegal objective-namely, discriminatory relief that the government may not lawfully provide-and may be subject to damages.

Yet the illegal-objective approach fails to persuade, for two related reasons. First, the assumption at its core is attractively phrased but inaccurate. Premier states that "[a] request for something that, if granted, is unlawful, is also unlawful." ${ }^{\text {105 }}$ This statement is not universally true; the First Amendment protects, for example, the right of a citizen to ask the President to undertake illegal action. ${ }^{106}$

${ }^{104}$ Courts have uniformly held that meritless claims against a handicapped homeseeker may violate the FHA. See, for example, Schroeder v De Bertolo, 879 F Supp 173, 178 (D PR 1995) (Groundless civil claims brought by condominium association against mentally ill member may constitute violation of $\S 3617$.).

${ }^{105}$ Premier, 814 F2d at 376.

106 Compare Gorman Towers, Inc. v Bogoslavsky, 626 F2d 607, 615-16 (8th Cir 1980) (First Amendment protects citizens' right to lobby for allegedly unconstitutional action.). 
Second, and at a more basic level, the illegal-objective exception must be rejected because it contains no limiting principle. Whenever a litigant asks a court to enforce a contract that is later deemed invalid, or to grant immunity from tort liability where no such immunity exists, or to issue a favorable but incorrect statutory interpretation, that litigant has asked for relief that is ultimately shown to be "illegal." An obvious circularity is at work here: the objective is illegal for the same reason that the lawsuit failed. If the illegal-objective test were taken literally, every losing plaintiff could find himself subject to liability, simply for having sought relief.

Judge Easterbrook's reasoning in Premier suggests a narrower version of the illegal-objective standard, but this version is ultimately unpersuasive as well. Premier draws a distinction between relief the government may lawfully provide (politically enacted restraints on trade) and relief it may not lawfully provide (enforcement of private cartels). By analogy, one might argue that a state court lawsuit to enforce a privately imposed restrictive covenant that discriminates on the basis of handicap could serve as the basis for damages under the FHA, whereas a lawsuit to apply a facially neutral zoning code would not. ${ }^{107}$ Yet this argument rests on an outmoded distinction between private and state action. ${ }^{108}$ It is nearly impossible to distinguish public rules that enforce private agreements from those that do not, as the Supreme Court recently noted in the antitrust context. ${ }^{109} \mathrm{~A}$ restrictive covenant, for example, may bar nonresidential uses of a property. When neighbors ask a state court to conclude that a proposed group home is of an inherently commercial rather than a residential character, does their action seek to implement a neutral rule of law or to enforce a discriminatory private agreement? ${ }^{110}$ The elusiveness of the question illustrates the intractsoility of the illegal-objective approach.

107 Of course, enforcement of a racially restrictive covenant is illegal a fortiori on constitutional grounds. Shelley $v$ Kraemer, 334 US 1, 23 (1948). See also Robinson, Fair Housing-Fair Lending Cas (P-H) II 15,979 at 15,979.7.

108 See Cass R. Sunstein, The Partial Constitution 160 (Harvard 1993) (discussing enforcement of private restrictive covenant as state action).

109 Omni Outdoor Advertising, 499 US at 375 ("Since it is both inevitable and desirable that public officials often agree to do what one or another group of private citizens urges upon them, such an exception would virtually swallow up the Parker rule.").

110 See Rhodes v Palmetto Pathway Homes Inc., 303 SC 308, 400 SE2d 484, 486 (SC 1991) (holding that FHA bans enforcement against group home of commercial-only restrictive covenant). 


\section{A PRoposed STANDARD OF LIABILITY FOR LITIGATION ACTIVITY UNDER THE FAIR HOUSING ACT}

\section{A. An Intent-Based Abuse of Process Model}

Courts should adopt a standard of Fair Housing Act liability for litigation activity based on the concept of discriminatory intent. State court lawsuits that are groundless, or are brought to burden, harass, or intimidate a disfavored homeseeker on the basis of impermissible criteria, should be subject to liability under the FHA. This approach is modeled on a modified version of the common law tort of abuse of process. Unlike the malicious prosecution tort invoked by the Court in Professional Real Estate Investors, ${ }^{111}$ an abuse of process claim is not defeated by a showing that the defendant had probable cause to bring the underlying lawsuit. ${ }^{112}$ Instead, abuse of process is defined in terms of the defendant's purpose in bringing the action: "One who uses a legal process, whether criminal or civil, against another primarily to accomplish a purpose for which it is not designed, is subject to liability to the other for harm caused by the abuse of process." 113

Judge Posner has taken a similar approach in interpreting the sham exception to Noerr-Pennington. Although this view has been rejected by the Supreme Court as a matter of antitrust law, ${ }^{114}$ it is still analytically helpful in the Fair Housing Act context. Writing for the Seventh Circuit in Grip-Pak, Inc. $v$ Illinois Tool Works, Inc., Judge Posner questioned whether litigation activity should be insulated from antitrust liability merely because it has some prospect of success on the merits: "If all nonmalicious litigation were immunized from government regulation by the First Amendment, the tort of abuse of process would be unconstitutional-something that, so far as we know, no one believes." ${ }^{115}$ According to Judge Posner, the existence of the abuse of process tort is proof that some meritorious lawsuits are filed for ulterior reasons-for example, to impose prohibitive litigation costs on a competitor, or to obtain trade secrets through discovery: "Many claims not wholly groundless would never be sued on for their own sake; the stakes, discounted by the proba-

11 See text accompanying note 64.

112 Restatement (Second) of Torts $\$ 682$ comment a (1977).

113 Id $\$ 682$.

114 Professional Real Estate Investors, 508 US at 65-66.

115694 F2d 466, 471 (7th Cir 1982). 
bility of winning, would be too low to repay the investment in litigation." 116 Thus, Judge Posner would retain only the second part of the Professional Real Estate Investors test, asking whether the federal defendant filed the state suit "strategically" in order to restrain trade through the process, rather than the outcome, of litigation. If that test is satisfied, then the lawsuit stands outside Noerr-Pennington's protective scope, and may constitute an antitrust violation even if it has some legal merit. ${ }^{117}$

A modified version of the Grip-Pak standard is appropriate in the context of the FHA. If the state court plaintiffs brought their zoning action in order to burden, harass, or intimidate a member of a protected class, then the possible legal validity of their claim should not insulate them from liability under the FHA. Like Judge Posner's model, this approach skips the first prong of the antitrust sham test (whether the state court claim had a legal or factual basis), and asks only whether the filing and prosecution of the lawsuit were motivated primarily by impermissible factors. ${ }^{118}$ Unlike in Grip-Pak, though, the primary motivation behind the lawsuit would not be determined by economic analysis, but by an inquiry into discriminatory intent.

The intent-based standard is consistent with the FHA's substantive provisions. The FHA explicitly prohibits making housing unavailable, or discriminating in terms or conditions, "because of race, color, religion, sex, handicap, familial status, or national origin." $" 119$ Its anti-intimidation provisions, in turn, are keyed to these core provisions. ${ }^{120}$ When local residents file suit against a group home for the handicapped in order to impose financial and nonfinancial costs on an unwanted neighbor, their activities fall squarely within the FHA's prohibitions. ${ }^{121}$

116 Id at 472.

117 Judge Posner's quantitative approach might not translate well to exclusionary zoning suits. Grip-Pak defines a lawsuit as a sham if a rational plaintiff, taking into consideration only the costs of litigation and the expected recovery, would refrain from filing it. Typically, zoning lawsuits brought by local residents are injunctive in nature, seeking to prevent a new resident from entering the community. Injunctive relief is notoriously difficult to quantify in economic terms.

118 By analogy, courts have held that an eviction violates the FHA when the landlord singles out a minority tenant.who was in arrears from among nonminority tenants who were also late with their rent payments. See, for example, Khawaja $v$ Wyatt, $494 \mathrm{~F} \mathrm{Supp}$ 302,303 (W D NY 1980).

${ }_{119} 42$ USC $\S \S 3604(a), 3604(b)$ (emphasis added). By contrast, civil liability may be imposed under the antitrust statutes without a showing of anticompetitive intent. United States v United States Gypsum Co., 438 US 422, 436 n 13 (1978).

12042 USC $\S \S 3617,3631$.

121 The proposed standard would require courts to decide whether discriminatory 
Under the proposed test, groundless claims would still give rise to liability under the FHA. On the other hand, if the plaintiffs prevail in state court, they should be immune from liability. Although the black-letter definition of abuse of process does not exempt successful suits, ${ }^{122}$ treating them as grounds for liability in this setting could lead to serious tension between state and federal courts.

Two recent cases involving religious discrimination illustrate how such a claim might work in practice, although neither explicitly adopted the abuse of process standard. In the Second Circuit case of LeBlanc-Sternberg $v$ Fletcher, a resident organization in the newly incorporated village of Airmont brought zoning challenges against Hasidim who sought to establish places of worship in their homes; the plaintiffs claimed the home synagogues would create noise and traffic. ${ }^{123}$ The Hasidim presented evidence that the residents had not challenged other developments, such as a recreational lake, a refreshment stand, and a country club, despite the fact that the club was described by one witness as a source of significant traffic and noise. The president of the resident organization had argued against opposing the country club, reasoning that if the club were closed, its owner "was going to sell it to the Orthodox people to live on."124 Similarly, the association voted unanimously not to challenge a Catholic mausoleum whose steeple was taller than the code allowed, "because this is the Catholic church that wants it."125 When the organization eventually dropped one of its zoning challenges against the Hasidim, one board member reasoned that "there are other ways we can harass them." ${ }^{126}$ The court concluded that the group's selec-

intent must be shown with respect to each complaining resident. Presumably, the intent of one or more vocal members of a neighborhood association could be imputed to the other members in some circumstances.

122 Restatement (Second) of Torts $\S 682$ comment a (cited in note 112) (For abuse of process purposes, "it is immaterial ... that the proceedings terminated in favor of the person instituting or initiating them."). In the antitrust context, see Fischel, $45 \mathrm{U}$ Chi L Rev at $111 \mathrm{n} 160$ (cited in note 53) ("I]f the Noerr-Pennington exemption rests on the first amendment, the success of the petitioning activity should not be dispositive: lobbying activity characterized by abusive tactics should not enjoy antitrust immunity even if successful.").

${ }^{123} 67$ F3d 412, 421 (2d Cir 1995). The district court opinion in the same case is discussed in the text accompanying notes 86-88.

124 Id.

${ }^{225} \mathrm{Id}$.

126 Id at 420 . 
tive zoning challenges constituted discrimination in violation of the FHA. ${ }^{.27}$

Similarly, in Tizes $v$ Curcio, a Jewish couple purchased two houses in Chicago's exclusive Astor Street neighborhood and obtained a special permit to convert the houses into a single home. ${ }^{28}$ A neighborhood association repeatedly challenged the issuance of the permit in state court. The neighbors also harassed the Tizes with ethnic slurs and other affronts. The district court held that the neighbors' litigation activity constituted actionable discrimination under the FHA. Although the court accepted Noerr-Pennington without discussion as a First Amendment doctrine, it concluded that uses of "the petitioning process primarily, if not exclusively, to harass or to discriminate" against members of a protected class violate the FHA. ${ }^{29}$ It also noted that the filing of the zoning appeal could not be separated from the totality of harassing behavior undertaken by the neighbors. ${ }^{130}$

Some modifications to the traditional tort of abuse of process are necessary in the FHA context. Abuse of process traditionally requires that the underlying lawsuit be filed primarily to impose collateral costs on the defendant; that is, to gain a benefit for which the judicial procedure in question was not designed. ${ }^{131}$ In some FHA cases this requirement will be easily met. The special permit appeal process at issue in Tizes, for example, was designed to ensure that building renovations comply with historic preservation standards and other land use rules. ${ }^{132}$ The use of this process to harass and delay a family on the basis of their religion was clearly improper. A more difficult case is presented where the plaintiffs' apparent purpose is not to harass or intimidate the defendant, but to win the relief sought on the face of their complaint, namely, to exclude the homeseeker. On the one hand, such a lawsuit does not seek collateral gains within the traditional meaning of abuse of process. On the other hand, the

\footnotetext{
127 Id at 435.

1281995 LEXIS $11368, * 2$ (N D $\mathrm{Hl})$.

129 Id $* 13$.

130 Id $* 14$.
}

131 See Restatement (Second) of Torts $\S 682$ comment b (cited in note 112) ("For an abuse of process to occur there must be use of the process for an immediate purpose other than that for which it was designed and intended."); Powers $v$ Leno, 24 Mass App Ct 381, 509 NE2d 46, 48-49 (1987) (filing of zoning action may constitute abuse of process if plaintiff had ulterior extortionate purpose).

132 Tizes, 1995 US Dist LEXIS $11368 * 3-4$. 
FHA was enacted precisely in order to prohibit the exclusion of homeseekers because of their minority or handicapped status.

Such claims should be governed by the conventional test for discriminatory intent under the FHA. To make out a case under this test, the plaintiff must make a threshold showing of discrimination; the defendant must then offer a legitimate, nondiscriminatory reason for his acts. ${ }^{133}$ Similarly, in a case alleging unlawful litigation, once a prima facie showing of discriminatory intent has been made, the burden should shift to the state court plaintiffs to show that they were using the zoning or judicial process for its intended purpose, rather than as a vehicle of discrimination. In LeBlanc-Sternberg, for example, the neighborhood association's failure to challenge nonsynagogue building developments stood as powerful evidence that the group was using zoning challenges to harm the Hasidim, rather than for their intended purpose of ensuring peace and quiet in the community. Under certain circumstances, then, a lawsuit filed with the intent to exclude a homeseeker on the basis of impermissible criteria should give rise to damages under the FHA, even if the state court plaintiffs did not use the judicial process to harass or impose collateral costs. ${ }^{134}$

The proposed standard, unlike Noerr-Pennington, would not immunize a discriminatorily motivated lawsuit merely because it had some basis in law or fact. Yet, unlike the illegal-objective standard, it would not expose to liability every unsuccessful zoning suit that happened to be filed against a member of a protected class. Instead, it provides a middle ground between the existing standards while conforming to the notion of discriminatory intent embodied in the FHA's provisions.

${ }^{133}$ See McDonnell Douglas Corp v Green, 411 US 792, 801-02 (1972) (establishing test for Title VII); HUD v Blackwell, 908 F2d 864, 870 (11th Cir 1990) (applying test to FHA). Most of the circuit courts have adopted a disparate impact standard under the FHA. See Schwemm, Housing Discrimination: Law and Litigation $\S 10.4$ at 10-17 to 10-38 (cited in note 39). Disparate impact liability for litigation activity, however, would be tantamount to an "illegal-objective" approach, under which all preempted state court suits could give rise to liability. See note 134.

134 Under the illegal-objective approach, by contrast, all unsuccessful suits against a member of a protected class could theoretically give rise to damages. For example, a land use decision that would have a disparate impact on protected groups could not lawfully be petitioned for, even absent discriminatory intent. Such a standard would have an unacceptable chilling effect on lawful petitioning activity. See text accompanying notes 148-49. 


\section{B. First Amendment Considerations}

The proposed standard is fully consistent with the First Amendment. The fact that this approach requires an inquiry into the intent of the state court plaintiffs does not render it unconstitutional. The Supreme Court has long held that speech may not be regulated simply because it espouses disfavored, even hateful, ideas. ${ }^{135}$ Yet the Court has also emphasized that "First Amendment rights may not be used as the means or the pretext for achieving 'substantive evils'... which the legislature has the power to control."136 In particular, civil rights statutes may constitutionally regulate expression that is accompanied by discriminatory forms of conduct, as the Court reiterated in a recent opinion upholding a Wisconsin "hate crime" statute:

[M]otive plays the same role under the Wisconsin statute as it does under federal and state antidiscrimination laws, which we have previously upheld against constitutional challenge. ... Title VII, for example, makes it unlawful for an employer to discriminate against an employee "because of such individual's race, color, religion, sex, or national origin." In [Hishon $v$ King \& Spalding, 467 US 69 (1984)], we rejected the argument that Title VII infringed employers' First Amendment rights. And more recently, in R.A.V. v. St. Paul, we cited Title VII (as well as 18 U.S.C. $\S 242$ and 42 U.S.C. $\S \S 1981$ and 1982) as an example of a permissible contentneutral regulation of conduct. ${ }^{137}$

The Court has long recognized that lawsuits involve conduct as well as mere speech. The Bill Johnson's Court, for example, in construing a provision of the NLRA similar to $\S 3617$ of the FHA, noted that a "lawsuit no doubt may be used ... as a powerful instrument of coercion or retaliation." ${ }^{\text {"138 }}$ Lawsuits, unlike pure

${ }^{135}$ See, for example, Police Department of Chicago v Mosley, 408 US 92, 95 (1972) ('[T]he First Amendment means that government has no power to restrict expression because of its message, its ideas, its subject matter, or its content.").

${ }^{136}$ California Motor Transport, 404 US at 515. See also Giboney $v$ Empire Storage \& Ice Co., 336 US 490, 502 (1949) ("[T]t has never been deemed an abridgement of freedom of speech or press to make a course of conduct illegal merely because the conduct was in part initiated, evidenced, or carried out by means of language, either spoken, written, or printed.").

${ }^{137}$ Wisconsin v Mitchell, 113 S Ct 2194, 2200 (1993) (citations omitted) (emphasis in original).

${ }^{138} 461$ US at 740. See also United Mine Workers $v$ Illinois State Bar, 389 US 217, 226 (1967) (Harlan concurring) ("[L]itigation is more than speech; it is conduct. And the States may reasonably regulate conduct even though it is related to expression."). 
expression, force defendants into court against their will and typically impose heavy and unavoidable costs, both financial and nonfinancial. ${ }^{139}$ In terms of the FHA's provisions, a lawsuit can harass or intimidate a homeseeker (in violation of $\S 3617)^{140}$ or effectively make housing unavailable (in violation of $\S 3604$ ). ${ }^{141}$ The FHA's coverage of discriminatory eviction and foreclosure actions amplifies the point. ${ }^{142}$

The constitutionally unprotected nature of litigation activity is particularly clear under an abuse of process standard. A lawsuit that meets this standard seeks to impose costs on the defendant separate and apart from the purposes of the chosen judicial procedure. Litigation activity has First Amendment relevance only insofar as it furthers the purposes of the right to petition: submitting one's legitimate grievances to a court for adjudication. ${ }^{143}$ It is not inconsistent with the First Amendment to conclude that a plaintiff who exploits the judicial process in order to impose costs on a defendant because of that defendant's handicapped or minority status should be required to bear those costs.

Imposing damages for discriminatory lawsuits does not represent a constitutionally suspect departure from established practices, for three reasons. First, the remedy is closely analogous to a fee-shifting rule. As Judge Easterbrook noted in Premier, such rules simply "require[ ] the party that creates the costs to bear them."144 Requiring a losing litigant, whether plaintiff or defendant, to reimburse the prevailing party for the

139 Other forms of petitioning and expression, such as town meetings, letter-writing campaigns, media contacts, and testimony at zoning hearings, lack this coercive quality and ought to enjoy greater immunity under the First Amendment. See White $v$ Julian, 1996 US Dist LEXIS 2116, *2-3, 12-14 (N D Cal) (First Amendment protects public meetings and circulation of newsletter in opposition to homeless shelter.); Michigan Protection and Advocacy Service, Inc. $v$ Babin, 799 F Supp 695, 720 (E D Mich 1992), aff'd, 18 F3d 337 (6th Cir 1994) (First Amendment protects neighbors' protests against group home.). For the related argument that the First Amendment protects such activities, but guarantees only a limited right to petition the courts because courts do not constitute a "public forum" for petitioning activity, see McGowan and Lemley, 17 Harv J L \& Pub Policy at 382-89 (cited in note 92).

${ }_{140}$ See, for example, Tizes, 1995 US Dist LEXIS $11368 * 13$.

${ }^{141}$ For example, in HUD $v$ Simpson, 1994 WL 497538, *11-12 (HUD ALJ), an administrative law judge held that the filing of numerous lawsuits in various state courts, accompanied by racial slurs, letter writing, harassing confrontations, and trash dumping, constituted a pattern of vexatious conduct that effectively kept the Peruvian-American plaintiffs from occupying or rehabilitating their house.

142 See text accompanying notes 31-37.

${ }^{143}$ See California Motor Transport, 404 US at 512-13 (misuse of judicial forum not protected by First Amendment).

144 Premier, 814 F2d at 373. 
costs engendered by litigation poses no constitutional problems. ${ }^{145}$ Second, unlike a suit injunction, a retrospective damages remedy imposes no prior restraint. ${ }^{146}$ Finally, the same solution has already been approved in the labor law context. It will be recalled that Bill Johnson's authorizes the NLRB to award costs and other appropriate damages to an employee who has defended a retaliatory lawsuit, even if that lawsuit is not judged to have been meritless. ${ }^{147}$

It might be argued that an intent-based standard impermissibly chills the exercise of the right to sue. ${ }^{148}$ On this view, the First Amendment should immunize all nonfrivolous suits, even discriminatory ones, thereby creating a "buffer zone" to lessen the risk that valuable litigation activity will be deterred. Perhaps the best known example of such overprotection is New York Times Co. $v$ Sullivan, which superimposed a requirement of "actual malice" onto common law libel in public-official defamation cases in order to promote vigorous debate on public issues. ${ }^{149}$ The illegal-objective approach, which would convert every successful Fair Housing Act zoning defense into grounds for recovery, would indeed have such an unwelcome chilling effect. Yet the requirement of discriminatory intent-like the requirement of actual malice in New York Times-ensures that local residents will not be deterred from good-faith resort to the judicial process in land use cases.

\section{CONCLUSION}

In enacting the Fair Housing Act, Congress established a national policy of equal access to housing for all people. This policy was intended to supersede local land use rules and deci-

${ }_{145}$ The FHA gives courts and administrative law judges discretion to award attorneys' fees to prevailing parties. 42 USC $\S \S 3612(p), 3613(c)(2), 3614(d)(2)$. Perhaps federal courts in cases alleging illegal litigation under the FHA could award the costs incurred by the federal plaintiff as a state court defendant. Compare Joseph J. Brecher, The Public Interest and Intimidation Suits: A New Approach, 28 Santa Clara L Rev 105, 137-40 (1988) (advocating immediate cross-claims and attorneys' fees for public-interest defendants).

146 See note 78.

147 See text accompanying note 71.

148 Such concerns arguably underlie the Court's rejection of the abuse of process standard in antitrust cases. See Professional Real Estate Investors, 508 US at 69 (Stevens concurring) ("Access to the courts is far too precious a right for us to infer wrongdoing from nothing more than using the judicial process to seek a competitive advantage in a doubtful case.").

49376 US 254, 267 (1964). 
sions that discriminate against protected groups. State court lawsuits can serve as a powerful tool of harassment, intimidation, and interference. Lawsuits brought in order to burden protected homeseekers or exclude them from a neighborhood fall within the FHA's express prohibitions. At the same time, however, the right to sue deserves substantial protection. Courts have used inconsistent standards in weighing these concerns. The Noerr-Pennington doctrine holds that the Sherman Act may not be read to regulate nonfrivolous lawsuits. However, this doctrine, which is based on the limited vision of federalism that underlies the antitrust laws, should not be transferred mechanically to the Fair Housing Act context. Nor should lawsuits automatically give rise to damages when they seek an illegal objective. Instead, lawsuits should be subject to liability under the FHA when they are intentionally targeted to harm protected groups. Such a standard would strike an appropriate balance between protecting equal access to housing and ensuring access to the courts. 